\title{
Prednost izračunavanja razgovornih implikatura pred njihovim poništavanjem: argumentacijski pristup
}

Martina Blečićc*

\begin{abstract}
According to H. P. Grice, the two main features of conversational implicatures are their calculability and their cancellability. Here I present the idea that these two features are in conflict with each other. In the paper I link the calculability of implicatures with argumentation theory and rationality and distinguish between formal cancellability and communicational deniability. Then, in order to solve the conflict between calculability and deniability, I argue for the priority of calculability over cancellability. I defend this position by presenting the calculation of implicatures as the reconstruction of arguments. Consequently, the priority of their calculability over their cancellability, or more correctly, their deniability, should lead to new insights related to the communicational responsibility of the speaker for the content that competent hearers read from his or her utterance.
\end{abstract}

Key words: conversational implicature, argumentation, communicational responsibility, cancellability, deniability

\footnotetext{
*Sveučilište u Rijeci, Filozofski fakultet; mblecic@uniri.hr
} 


\section{Uvod}

U radu ću se posvetiti dvama značajkama razgovornih implikatura: mogućnosti da se one izračunaju i mogućnošću da se ponište ${ }^{1}$ te ću razmotriti mogućnost da su one međusobno isključive. Mogućnost njihova izračunavanja daje im stabilnost i objektivnost koja omogućuje njihovo korištenje u govornoj zajednici te je kao takva u suprotnosti s idejom da govornik uvijek može komunikacijski uspješno poništiti implikaturu koju njegovo iskazivanje određenog sadržaja sa sobom nosi. Smatram da je mogućnost njihove rekonstrukcije, i to rekonstrukcije u obliku argumenta, ono što im daje komunikacijsku snagu te ću joj dati prednost pred poništavanje. U radu ću predložiti viđenje po kojemu ih se može tretirati kao razložne argumente u kojima je samo jedna premisa izrečena. Nakon toga ću se posvetiti svojstvu implikatura da budu poništene i razlikovati ga od mogućnosti njihovog poricanja. Poništavanje ću predstaviti kao značajku sadržaja implikature, a poricanje kao odricanje govornika od komunikacijske namjere. Predložit ću ideju da je takvo poricanje moguće ako ne dovodi do kontradikcije u vidu nekonzistentnog skupa premisa, te na taj način povezati argumentacijski pogled na implikature i njihovo nijekanje. Takav stav imat će posljedice i za proučavanje implikatura u spoznajnom i moralnom kontekstu te za ideju o komunikacijskoj odgovornosti, no ta će pitanja u ovom radu ostati samo naznačena.

Neću ovdje razlagati Griceovu teoriju o značenju i raznim vrstama implikatura, a neću u uvodnom dijelu niti davati primjere ove pragmatičke komunikacijske strategije; s njima ce se čitatelj susretati u daljnjem dijelu teksta. Ukratko, možemo reći kako su razgovorne implikature (Grice 1987, 1995) konverzacijska strategija pri kojoj prava poruka nije formalno vezana uz rečenicu iz koje izvire, ali se na temelju nje mora moći rekonstruirati, to jest, izračunati. Kolokvijalno rečeno, radi se o naznakama, insinuacijama, točnije, sadržaju neizravno prenesenom verbalnim sredstvima. Grice završava članak „Logika i razgovor" nabrajanjem svojstava koje razgovorne implikature moraju posjedovati, a upravo su one interesno središte ovog rada. Ta su svojstva sljedeća:

1. Mogućnost poništavanja - kako bismo pretpostavili postojanje razgovorne implikature moramo pretpostaviti da se sudionici u komunikaciji pridržavaju načela suradnje. S obzirom na to da se sudionici ne moraju pridržavati tog principa, razgovorna implikatura se može poništiti. Takvo opovrgavanje može biti eksplicitno, dodavanjem dijela u kojemu se implikatura odbacuje, ili kontekstualno, u slučajevima u kojima su uvjeti u kojima dolazi do iskazivanja dovoljni da ponište implikaturu.

\footnotetext{
1 Može se postaviti pitanje o tome koja je od ove dvije značajke implikatura temeljna, no u literaturi nećete pronaći jedinstven odgovor. Na primjer, Blome-Tillmann (2008: 156) govori kako je test poništavanja najpouzdaniji indikator toga da je pojava koju ispitujemo zaista razgovorna implikatura, a ne neka druga jezična pojava. Ipak, nadam se da ću u ovom radu pokazati kako je mogućnost da se implikature izračunaju važnije od njihovog poništavanja, ili, još važnije, poricanja.
} 
2. Neodvojivost - ovo svojstvo očituje se u tome da je nemoguće odvojiti jezični iskaz (u konkretnoj govornoj situaciji, tj. kontekstu) od implikature koju sa sobom povlači, to jest nije moguće reći istu stvar na neki drugi način, a da ne bude prisutna i jednaka implikatura.

3. Razgovorne implikature barem u početku nisu dio značenja izraza uz koje se vežu, no moguće je da čestim korištenjem dođe do konvencionalizacije implikature.

4. Zbog toga što istinitost onog što se razgovorno implicira nije zadana istinitošću onog što je rečeno (ono što je rečeno može biti istinito, a ono što se implicira lažno), implikaturu ne nosi ono što je rečeno, već izgovaranje tog sadržaja.

5. S obzirom na to da se izvođenje razgovorne implikature sastoji od računanja onog što se treba pretpostaviti da bi se održala ideja da se naš sugovornik pridržava načela suradnje i zato što postoji mnoštvo specifičnih objašnjenja, ono što se implicira bit će disjunkcija takvih specifičnih objašnjenja. Ako je popis takvih objašnjenja otvoren, moguće implikature bit će neodređene (prema 1987: 66. i 67).

Kao što je već naglašeno, u radu ću se posvetiti samo značajkama vezanima uz mogućnost izračunavanja ${ }^{2}$, to jest, izvođenja implikatura i njihovog poništavanja. Izgleda kao da su ove dvije značajke u sukobu: s jedne strane izvođenje implikature mora biti argumentacijski dokazivo, a s druge strane slušatelj može jednostavno zanijekati implicirani sadržaj. Želja mi je pokazati kako je za implikature puno važnija mogućnost njihovog rekonstruiranja od mogućnosti da se ponište. Imajući na umu razlikovanje između formalnog poništavanja i poricanja govornikove namjere zalagat ću se za veću govornikovu odgovornost pri neizravnoj komunikaciji koja može biti korisna u raspravama iz teorije spoznaje i etike.

\section{Razgovorne implikature $\mathrm{i}$ argumentacija}

Smatram kako gledanje na rekonstrukciju razgovornih implikatura kao na rekonstrukciju argumenata daje epistemičku snagu vjerovanju koje slušatelj stvara na temelju neizravno prenesenog sadržaja. Ideji da se na implikature ne mora gledati samo kao na inferencije, već $\mathrm{i}$ kao na cjelovite argumente možda nije dobila zasluženu pažnju, no nije ni sasvim nepoznata. Macagno i Walton, koji dolaze iz pragma-dijalektičke struje unutar teorije argumentacije, razgovorne implikature određuju kao objašnjenja nekonzistentnih dijaloških i epistemičkih pretpostavki. Primjere razgovornih implikatura možemo objasniti tako da pretpostavimo slušateljevo čuđenje zbog govornikove poruke zahvaćene na semantičkoj razini - je li zaista to rekao ili time želi poručiti nešto drugo? Ipak,

\footnotetext{
2 Mogućnost izračunavanja implikatura ne smije se miješati s njihovom interpretacijom. Interpretacija implikatura može biti automatska i nerefleksivna, no kompetentni korisnici jezika moraju način na koji su došli do sadržaja implikature (implicatuma) moći rekonstruirati post facto (vidi npr. Haugh 2008).
} 
takvu čuđenje nije nemetodično te Walton i Macagno govore kako „razgovorne implikature treba analizirati kao implicitne argumente koji uključuju obrasce zaključivanja koji vode od zadane premise do zaključka." (Walton i Macagno 2013: 211).

Sagledajmo sljedeći primjer.

Ivan: Jesi li spremna za kino?

Ana: Umorna sam.

Prema sistematizaciji koju pružaju autori, on se može objasniti kao argument iz uzroka, to jest, kao vrstu uzročne argumentacije u kojoj se događaj povezuje s uzrokom koji je do njega doveo. Općenita shema je sljedeća:

Velika premisa: Općenito možemo reći da će se B dogoditi (ili da se može dogoditi) ukoliko se A dogodi.

Mala premisa: U ovom slučaju dogodilo se A (ili se može dogoditi).

Zaključak: Stoga, u ovom slučaju B će se dogoditi (ili se može dogoditi) (ibid:

219)

U navedenom primjeru Ana odgovara da je umorna umjesto da pruži izravan odgovor na pitanje je li spremna za odlazak u kino. Cilj njezinog iskaza nije obavijestiti Ivana o njezinom psihofizičkom stanju, već ga navesti da s uzroka zaključi na posljedicu. Umor je, barem načelno, nekompatibilan s odlaskom u kino: ako je netko umoran, onda mora ostati kod kuće. Ako netko ostane kod kuće, ne može pogledati film u kinu. Takva uzročna veza predstavljena kao izbor. Ili A ili B, ne A, stoga B (prilagođeno prema 219).

Sagledajmo sada kakvi argumenti razgovorne implikature uopće mogu biti. Moldovan (2012) navodi kako je važno naglasiti kao se „argument“ ponekad koristi kako bi se referiralo na govorni čin raspravljanja, a ponekad na apstraktni predmet, koji je sadržaj izražen govornim činom raspravljanja. Prema njemu, pitanje koje ovdje razmatramo treba sročiti ovako: „je li razgovorna implikatura uvijek govorni čin raspravljanja?“ Moldovan zaključuje: „vjerujem kako je odgovor na ovo pitanje niječan.“ (Moldovan 2012: 303)

Kada bismo morali birati između toga jesu li razgovorne implikature govorni činovi raspravljanja ili apstraktni objekti mogli bismo se naći u iskušenju da u potpunosti odbacimo ikakvu vezu između implikatura i argumenata. U primjeru s odlaskom u kino Ivan mora do Anine poruke doći vlastitim zaključivanjem, no među njima nema sukoba koji treba razriješiti raspravom. Njihova komunikacija usmjerena je prema dijeljenju informacija. Takvo dijeljenje ostvaruje se razumijevanjem implikature koja se post facto može prikazati u obliku argumenta.

Ipak, opcije koje nam nudi Moldovan nisu jedini način gledanja na prirodu argumenata i argumentacije. U svojoj teoriji argumentacije Hitchcock piše kako se (u engleskom, ali slično razlikovanje možemo uvidjeti i u drugim jezicima) riječ „argument“ i s njom vezani glagol „argumentirati“ koriste se na dva jasno razlučiva načina. U prvom smislu „argumentirati zahtjeva samo jednog diskutanta (ili skupinu). Diskutant izražava stav 
o nekom pitanju te pruža jedan ili više razloga u korist svoje pozicije koji tvore skup govornih činova. Diskutant upućuje te govorne činove čitatelju, slušatelju ili promatraču (ili većem broju njih), koji ne mora odgovoriti (Hitchcock 2016: 448).

Drugi smisao je onaj u kojemu kažemo stvari poput „diskutirali su“ ili „diskusija je bila žustra“. Prema ovom smislu, za argumentaciju je potrebno barem dvoje diskutanta. Diskutanti međusobno izražavaju suprotne stavove i svaki od njih pokušava da drugi prihvate njegovo gledište, ne nužno tako što za njega pruža razloge (ibid. 449).

Dakle, prema Hitchcocku, argument može pružiti podupiruće razloge za nečiji stav ili mu cilj može biti uvjeriti suparnika u poziciju diskutanta koji ga koristi. Prvu vrstu argumenta naziva „razložni“, a drugu „disputacijski“ argument.

Za potrebe ovoga rada tvrdit ću kako se razgovorne implikature mogu smatrati razložnim argumentima pri kojima se govornik obraća slušatelju, koji ne mora odgovoriti, pružajući mu razloge za komunikacijski zaključak. U slučaju razgovornih implikatura govornik ne želi uvjeriti slušatelja da prihvati poziciju s kojom se ne slaže, već eksplicitno navodi razlog kojim se potkrjepljuje njegova poruka.

Kao što smo ranije vidjeli objašnjavajući primjer s odlaskom u kino kao argument iz uzroka, ukoliko je osoba umorna utoliko bi trebala ostati kući, a ako ostane kući ne može pogledati film u kinu. Eksplicitna premisa „Umorna sam“ pruža razlog za to da osoba ne ode u kino, to jest, za slušateljevo razumijevanje zaključka da osoba s kojim razgovara ne želi ići u kino. Zaključivanje u obliku ,ako se A ostvari, tada će se B ostvariti (ili bi se moglo ostvariti)“ premisa je koja nedostaje i koja povezuje eksplicitno izrečen razlog sa zaključkom. Zbog toga možemo rekonstruirati argument na kojemu se razgovorna implikatura temelji. Iskaz je premisa, to jest, jedina izrečena premisa argumenta, a ostale premise i zaključak ostaju neizrečeni.

Ono što bi se ovakvoj slici moglo prigovoriti jest da samo jedna izrečena premisa nije dovoljna da bismo mogli govoriti o argumentu. Ono što želim predložiti jest da su razgovorne implikature posebna vrsta entimema, to jest, skraćenog silogizma kojemu nedostaje zaključak ili premisa. Entimemi se mogu rekonstruirati na temelju elemenata koji su u njima eksplicitno prisutni koristeći induktivne, deduktivne ili abduktivne oblike zaključivanja ${ }^{3}$. Premise koje nedostaju obično se smatraju pretpostavkama potrebnim da bi argument bio valjan. Pripisivanje tih pretpostavki često će se opravdavati pozivanjem na milosrdnu interpretaciju prema kojoj premisa koja nedostaje argument mora učiniti valjanim ili barem snažnim. Kod entimema, osoba kojoj pripisujemo premisu ili zaključak nikad te elemente nije eksplicitno iznijela te stoga entimem nikada nije sasvim jednak argumentu koji se na njemu temelji. Taj argument jest prikaz onoga što se entimemom htjelo poručiti. Isto možemo reći za argumente koje izražavaju razgovorne implikature. Argument koji se na temelju iskaza može rekonstruirati nikada nije jednak samom is-

\footnotetext{
3 Ove se vrste zaključivanja razlikuju po snazi inferencije koja iz njih proizlazi. Indukcija je povezana sa statističkim zaključivanjem, dedukcija je monotonična, dok abdukciju određuje plauzibilnost zaključivanja koje se može pobiti.
} 
kazu, no može biti vjerodostojan prikaz njegove strukture i njegovog komunikacijskog sadržaja. Prema Gilbertu (1991) nepotpune argumente treba upotpuniti pretpostavkama koje su za ciljanu publiku uvjerljive i koje se uklapaju u stav koji zagovara govornik, naravno, ako ne postoje dokazi koji upućuju na suprotno. Primjenjujući te ideje na razgovorne implikature kao razložne argumente možemo reći kako premise koje nedostaju moraju biti popunjene pretpostavkama koje su plauzibilne slušatelju i koje se, barem naizgled, uklapaju u govornikov stav i poruku koju želi prenijeti. Argumenti za koje možemo reći da ih izriču implikature, ili koji se na temelju njih mogu rekonstruirati, uvijek će sadržavati dozu nesigurnosti, to jest, neće imati snagu dedukcije, koja ne dopušta iznimke. Ipak, takvo što je sasvim uobičajeno u svakodnevnom zaključivanju (vidi Mercier i Sperber 2017: 163. i 164).

Nadam se da sam uspjela predstaviti razgovorne implikature kao jezičnu strategiju koja, iako do njene interpretacije najčešće dolazi automatski, može rekonstruirati u obliku argumenta. Kao što smo vidjeli u uvodnom dijelu, i sam Grice je mogućnost rekonstrukcije implikatura smatrao krucijalnom te ih je smještao u širi kontekst ljudske racionalnosti (vidi npr. Grice 1987: 59).

Da ukratko ponovim: smatram kako se argument izražen razgovornom implikaturom može klasificirati kao razložni, to jest, kao argument kojim govornik pruža razloge ne očekujući od sugovornika njihovo opovrgavanje. Ono što je specifično za razgovorne implikature jest da slušatelj mora moći rekonstruirati argument na temelju razloga koje je govornik dao i koji su jedina izrečena stavka tog argumenta. U takvoj argumentaciji argument nastaje spontano interakcijom između govornika i slušatelja, a njegova formalna rekonstrukcija samo je naknadna posljedice te interakcije ${ }^{4}$.

U prvom dijelu ovoga rada Griceovu ideju o kalkulabilnosti implikatura povezala sam s idejom da se na partikularizirane razgovorne implikature može gledati kao na argumente, ili preciznije rečeno, da ih se može rekonstruirati u argumentacijskom obliku. Smatram da takva rekonstrukcija osnažuje ovu pragmatičku strategiju pružajući joj stabilnost. Pragmatički obrasci koji se na ovaj način stvaraju omogućavaju razumijevanje implikatura koje ne ovisi toliko o ispravnom ǐ̌citavanju govornikove namjere, već o ispravnom slijeđenju obrazaca ${ }^{5}$.

Prije no što pređem na mogućnost poništavanja implikatura u idućem dijelu pružit ću kratak uvid u još jedan aspekt implikatura koji pruža potporu ideji o važnosti izračunavanja pred poništavanjem. Riječ je o zadanim značenjima koja se mogu pojaviti kako na semantičkoj tako na pragmatičkoj razini.

4 Za ideju o zajedničkom stvaranju implikatura u interakciji govornika i slušatelja vidi Haugh (2008).

5 Za ideju kako je od govornikove namjere bitnije slušateljevo pripisivanje takve namjere vidi Sbisà (2001). 


\section{Razgovorne implikature i zadano značenje}

Teoretičari relevantnosti možda su i najpoznatiji nastavljači Griceovih teorija. Oni su od pragmatike načinili interdisciplinarno polje proučavanja koje spaja spoznaje iz filozofije, lingvistike i psihologije. Prema R. Carston (2002), Griceova je zasluga što je proučavanje jezika udaljio od pukog izučavanja koda te ukazao na važnost govornikove namjere koja na određeni način mora biti dostupna slušatelju. Međutim, daljnji teorijski razvoj na polju pragmatike pružio je njegovoj teoriji potrebne dopune i produbljenja. Prihvaćanje radikalne jezične neodređenosti uvodi pragmatičku inferenciju u samu izraženu propoziciju (,što je rečeno“), a sama pragmatika se iz društvenog i filozofskog pothvata pretvara u psihološko i neurološko razotkrivanje ljudskih kognitivnih procesa (Carston 2002: 206). No ukoliko želimo zadržati određenu dozu normativnosti pri izučavanju jezika, posebice u domenama epistemologije i etike, utoliko pragmatici moramo pružiti oblik koji se može vrednovati. Smatram da nam argumentacijski pristup pruža temelje za takav pothvat. Suvremeni pragmatisti često koriste ideju „istaknutog značenja“, koja će biti od važnosti i za ideje iznesene u ovom radu. Za razliku od relevantista (Sperber i Wilson 1986; Carston 2002), koji istaknuta značenja (poput pridavanja vremenskog sadržaja rečenici „Marko i Vesna vjenčali su se i postali roditelji“ ${ }^{\text {“6) }}$ pripisuju kontekstualno uvjetovanim pragmatičkim inferencijama, K. Jaszczolt ih objašnjava pomoću situacijski zadanih značenja. Jaszczolt $(2005,2010,2016)$ definira situacijski zadana značenja kao ona značenja do kojih se automatski dolazi u određenom razgovornom kontekstu. Prema autorici nije bitno jesu li takva značenja semantičko značenje, razgovorne implikature, impliciture (Bach 1994), eksplikature (Carston 2002) ili nešto peto; ono što je po njoj bitno jest da je takvo zadano značenje dodatak formalnom značenju koje nadilazi razlikovanje između implicitnog i eksplicitno. Jaszczolt zagovara „semantiku zadanih značenja“, koju određuje kao radikalniji kontekstualni postgriceovski pristup (2016), prema kojoj je poruka koju govornik želi prenijeti (ili primarno značenje) neovisna o logičkoj strukturi izgovorene rečenice. Zadanost autorica izjednačava s automatskom interpretacijom iskaza. Važno je naglasiti kako je automatska interpretacija o kojoj govori vezana uz pojedinu situaciju i govornike koji u njoj sudjeluju te ne vrijedi za sve govornike u svim kontekstima. Na primjer, gore spomenuta rečenica „Marko i Vesna vjenčali su se i postali roditelji“" nosi određenu vremensku konotaciju, no ona se ne mora aktivirati u kontekstu u kojemu sve osobe koje sudjeluju u razgovoru znaju da su se Marko i Vesna vjenčali nakon rođenja djeteta. Jednako vrijedi za rečenicu „Neki mamini kolege došli su na ručak“. Riječ „neki“ aktivirat će interpretaciju da nisu svi članovi skupa „mamini kolege“ došli, no to nije nužno tako; nema kontradikcije u rečenici „Neki mamini kolege došli su na ručak, zapravo, došli su svi“.

\footnotetext{
6 Na semantičkoj razni takav sadržaj ne postoji. Veznik ,i“ semantički je ekvivalentan logičkom vezniku „^“. Vremenska odrednica pragmatički je dodatak (vidi Grice 1987).
} 
Situacijski zadano značenje iskaza možemo definirati na sljedeći način: situacijski zadano značenje (ili skraćeno: zadano značenje) informacijski je sadržaj koji iskazu u danom kontekstu dodjeljuje kompetentni jezični korisnik s obzirom na relevantne spoznaje o svijetu.

Autorica svoju teoriju primjenjuje i na razgovorne implikature. Sagledajmo jedan od primjera koje navodi:

Dijete: Mogu li otići do ormarića po svoj mobitel?

Učitelj: Sat još nije gotov. (Jaszczolt 2016: 79)

„Sat još nije gotov“ na semantičkoj je razini minimalna propozicija. Ona se može nadopuniti informacijom da je riječ o školskom satu (eksplikatura), no ni to nije poruka koju govornik želi prenijeti. Ono što učitelj želi poručiti jest da učenik ne može otići do ormarića po svoj mobitel; upravo je to istaknuto, a time i primarno značenje ovog iskaza. $\mathrm{Na}$ taj način razgovorna implikatura postaje prvotno značenje iskaza te su ono semantički minimalno (vidi Borg 2004), kao i ono koje rezultira prvom razinom pragmatičke nadopune (eksplikaturom) komunikacijski sekundarna.

Jaszczolt navodi kako bi se netko mogao pitati koji su dokazi za teoriju o primarnim/”sekundarnim značenjima koja je u kontrastu s razlikovanjem između eksplicitnog/implicitnog sadržaja. Autorica na to odgovara konceptualnom analizom (vidi poglavlja 1 i 2 u 2016), a navodi da postoje i psihologijski dokazi, no ono što je posebno važno za ovaj rad je uloga koju pridaje poništavanju. Ipak, prije no što sagledamo način na koji autorica tretira poništavanje moramo sagledati o čemu je zapravo riječ.

\section{Poništavanje razgovornih implikatura}

Više je puta naglašeno kako je jedno od temeljnih svojstava implikatura prema Griceu mogućnost da budu opovrgnute, to jest, poništene. Riječima samog Gricea: „[...] navodna razgovorna implikatura da p može se eksplicitno poništiti ako je moguće, obliku riječi iskaza koji navodno implicira da p, dodati ali ne p, ili ne želim reći da p, te se može kontekstualno poništiti ako je moguće pronaći situacije u kojima iskaz tog oblika riječi jednostavno ne nosi implikaturu“ (Grice 1989: 44).

Već je iz ovog citata vidljivo kako svojstvo implikature da se može poništiti možemo shvatiti na više od jednog načina. Prvi je onaj u kojemu (navodnu) implikaturu poništavamo dodavanjem nastavka koji opovrgava da je postojala implikatura („Umorna sam, ali voljela bih pogledati film“). Drugi je onaj u kojemu zamišljamo situacije u kojima dani iskaz sa sobom ne nosi implikaturu; na primjer, iskaz „Umorna sam“ neće uvijek sa sobom povlačiti implikaturu „Ne želim u kino“. Ipak, kontekstualno poništavanje se ne mora sastojati u zamišljanju scenarija. Implikaturu „Ne želim u kino“ govornik može poništiti kontekstualno oblačeći kaput i uzimajući ulaznice sa stola dok izgovara 
„Umorna sam“. Već iz ovih primjera vidljivo je da je mogućnost opovrgavanja implikatura višeslojna te da se na nju može gledati iz više kutova. U nastavku ću pokušati objasniti razliku (i sličnosti) između „poništavanja“, „osporavanja“, „poricanja“ i „opcionalnosti“.

Mazzarella i suradnici (2018), sljedeći Leeja i Pinkera (2010) pišu kako poništavanje otvara vrata poricanju. „Sadržaj se može poreći ako govornik može zanijekati (kada ga se otvoreno izazove) da je ikad imao namjeru saopćiti ga. Poricanje i poništavanje ne preklapaju se: ono što se može poreći može se poništiti, no ono što se može poništiti ne može se nužno poreći (barem ne plauzibilno)“ (Mazzarella et al. 2018: 16). Sagledajmo primjer koji nude. Marija sumnja da njezin suprug ima aferu te pita prijateljicu Suzanu što misli o tome. Suzana odgovara: „Vidjela sam tvog supruga s nekom ženom u kinu pred koji dan." Marija interpretira iskaz kao potvrdu da njezin suprug ima aferu. Ipak, dolazi do saznanja da je njezin suprug bio u kinu, no bio je u društvu svoje sestre, koju Suzana dobro poznaje. Kada Marija od nje traži objašnjene Suzana se brani govoreći: „Nisam htjela reći da ima aferu. Žena s kojom je bio njegova je sestra.“ (ibid. 16) Prema Mazzarelli i suradnicima, u ovom slučaju Suzana može poništiti implikaturu, no teško će ju poreći. „Poništavanje je binarna kategorija (može se/ne može se poništiti), poricanje je pitanje stupnja te je funkcija diskursnih svojstava konteksta iskaza.“ (ibid. 16) Poricanje nije sasvim jezična kategorija jer uvelike ovisi o uvjerljivosti govornika.

Kada govore o plauzibilnom poricanju, Lee i Pinker (2010) daju sljedeći primjer razlikovanja između „poricanja“ $i$ „osporavanja“, koje možemo izjednačiti s poništavanjem. Implikatura se može osporiti ako ju iskaz logički ne povlači te se može poništiti ili otkloniti bez kontradikcije. Na primjer, „Neki su muškarci šovinisti“ prirodno navodi slušatelje da zaključe kako je govornik mislio i da neki muškarci nisu šovinisti. No ta implikatura nije logička implikacija te se može poništiti, kao u rečenici „Neki su muškarci šovinisti, zapravo, svi su“ (Pinker i Lee 2010: 791). Pinker i Lee opovrgavanje, za razliku od poništavanja, povezuju sa sebičnim interesima govornika te situacijama poput podmićivanja, diplomatskih odnosa i seksualnog uznemiravanja. Ako policajca koji se sprema napisati vam prometnu kaznu pokušate podmititi izravno možete se susresti s dvama scenarijima: ako je policajac podmitljiv izvući ćete se, no ako je pošten može vas kazniti zbog podmićivanja. S druge strane, ako to učinite neizravno (,Možda bismo to mogli riješiti bez papirologije“) potkupljivi policajac shvatit će poruku, a pošteni neće imati dovoljno čvrstih dokaza da vas optuži za mito.

Prema autorima, poricanje ne mora biti plauzibilno, već samo moguće. Prema njima to slijedi iz činjenice da se razgovorne implikature uvijek doživljavaju kao govorna strategija koja sa sobom ne nosi stopostotnu sigurnost. Na njihovom je tragu i Camp (2018) kada govori o insinuacijama. Prema njoj, u konfliktnim situacijama sugovornici pristaju minimalne standarde suradnje te se komunikacija odvija kroz nijansiranu igru poricanja i pedantnog raščlanjivanja primljene poruke.

Zaključno, razliku između poništavanja (osporavanja) i poricanja možemo objasniti na ovaj način: poništavanje je vezano uz sadržaj izrečene propozicije, uključujući neizravne 
poruke, dok je poricanje vezano uz govornikovu namjeru. U slučajevima poništavanja briše se informacijski sadržaj iskaza, a u slučajevima poricanja govornik niječe da je imao namjeru priopćiti slušatelju išcitanu poruku te postići određeni učinak.

Tu je razliku dobro imati na umu, jer miješanje pojmova može dovesti do nekonzistentnosti u literaturi. Tako se, na primjer, Weiner (2006) pita mogu li se sve implikature poništiti. Sugerira da ne mogu i navodi primjer dviju žena u vlaku. Alisa je mlada i zdrava žena koja je zauzela dva sjedala u vlaku. Sara bi voljela sjesti pa joj govori: „Pitam se je li fizički moguće da oslobodiš mjesta za još jednu osobu." Implikatura je jasna, Sara traži od Alise da se pomakne. Weiner traži od nas da zamislimo kako Sara dodaje „Ali ne želim da se pomakneš, samo sam znatiželjna.“ Prema autoru, to je eksplicitno poništavanje implikature, no implikatura ipak nije poništena, štoviše, pojačana je.

Dahlman (2013) i Åkerman (2014) pružaju sličnu kritiku Weinerovog primjera te se slažu oko toga da u njemu implikatura nije poništena, no naglašavaju kako se radi o ironičnoj opasci. Prema njima, ukoliko je implikatura ozbilina, utoliko i njeno poništavanje mora biti ozbiljno. Ipak, ako na umu imamo razlikovanje između poništavanja i poricanja, možemo reći da je i ovom primjeru implikatura poništena, no da poricanje komunikacijske namjere nije uspjelo.

Za kraj ovog dijela objasnit ću pojam „opcionalnosti“. Riječ je o razradi Griceove ideje o poništavanju implikatura prema kojoj su implikature neobavezne jer postoje konteksti u kojima se ne pojavljuju iako se koristi isti iskaz koji ih u nekom drugom kontekstu nosi sa sobom (vidi Lauer 2014). Iskaz „Možeš li doseći staklenku na polici?“ u određenom kontekstu bit će molba ili zahtjev za dodavanjem staklenke, no ako provjeravamo koliko je naš nećak narastao od našeg zadnjeg susreta neće doći do te implikature i „da“ ili „ne“ bit će zadovoljavajući odgovori.

Dakle, poništavanje (osporavanje) sadržaja možemo odrediti kao ispravku govornika koji je, možda zabunom, prenio pogrešan sadržaj. Takva ispravka ne mora biti vezana uz neizravni ili implicitni sadržaj. Ako netko umjesto riječi „mačka“ izgovori riječ „pas“ te se potom ispravi možemo reći da je poništio značenje svog iskaza. Poricanje je vezano uz govornikovu namjeru. Ako na primjer Ivan kaže „Ana je prava mačka“, slušatelj će vjerojatno zaključiti kako Ivan smatra da je Ana privlačna. Ako se Ana usprotivi takvoj objektifikaciji, Ivan načelno može reći da je htio reći kako je njen vid izvrstan, baš poput mačjeg, no takvo ograđivanje od komunikacijske namjere neće biti uvjerljivo. I za kraj, opcionalnost je vezana uz izostanak implikatura u određenim kontekstima. Iskaz „Hladno je“ u nekim će situacijama biti molba da se zatvori prozor, no ne u svima.

Sada se vraćamo na ulogu koju poništavanju, i srodnim pojavama, pridaje K. Jaszczolt te na njihov odnos s izračunavanjem implikatura. 


\section{Poništavanje i zadano značenje}

Prema Jaszczolt, poništavanje ne ovisi o tome je li sadržaj semantički ili pragmatički, izravan ili neizravan, doslovan ili nedoslovan; ono što je važno za mogućnost poništavanja jest to je li sadržaj primaran ili sekundaran. Ako su implikature dio primarnog značenja, tada se one neće moći poništiti. S druge strane, ako moguća implikatura nije dio primarnog, već sekundarnog značenja, tada ju je moguće poništiti. Primarno značenje je ono komunikacijski istaknuto, ono koje je plod situacijski zadane interpretacije. Ideju ćemo najbolje pojasniti pomoću primjera.

Marko i Vedrana razgovaraju o njezinom klavirskom koncertu.

Marko: Je li izvedba bila uspješna?

Vedrana: Neki su ljudi pljeskali.

U ovom primjeru razgovorna implikatura, to jest poruka da izvedba nije bila pretjerano uspješna, primarno je značenje iskaza. Ipak, to nisu sva značenja koja možemo izvesti. Još jedno pragmatičko značenje vezano je uz riječ „neki“. Skalarna implikatura (takozvana Hornova skala, vidi Horn 1984. i 1989) je ta da nisu svi ljudi pljeskali, no ona je u ovom kontekstu sekundarna. Primarnu poruku je, prema Jaszczolt, u ovom slučaju teško poništiti. Vedrana može reći ovo: „Neki su ljudi pljeskali, no to ne znači da izvedba nije bila dobra, većina je ranije otišla da uhvati zadnji vlak“. Prema autorici ovakva je reakcija moguća, no veoma je neobična kada se u obzir uzme da je to odgovor na pitanje o kvaliteti izvedbe. S druge strane, poništavanje sekundarne implikature jest plauzibilno: „NNeki su ljud pljeskali, zapravo, svi su to činili““.

Sagledajmo sad ponešto drugačiju verziju situacije:

Marko: Je li izvedba bila uspješna?

Vedrana: Da, bila je. Sala je bila puna i publika me nagradila gromoglasnim pljeskom.

U ovom primjeru primarno je značenje ono da je izvedba bila uspješna, to jest, doslovno i izravno prenesena poruka. Ipak, iz iskaza se može izvesti i implikatura da je Vedrana sretna zbog toga. Ta je implikatura slaba te se može lako poništiti:

Marko: Je li izvedba bila uspješna?

Vedrana: Da, bila je. Sala je bila puna i publika me nagradila gromoglasnim pljeskom, no nisam zadovoljna. Nisam bila dovoljno izražajna.

Implikatura da je Vedrana sretna zbog uspješne izvedbe sekundarno je značenje te se zbog toga lako može poništiti.

Važno je zapaziti kako ni Jaszczolt ne razlikuje između poništavanja i poricanja. Uzimajući to razlikovanje u obzir primjere možemo sagledati ovako:

Marko: Je li izvedba bila uspješna?

Vedrana: Neki ljudi su pljeskali. 
Implikatura u ovom primjeru jest ta da izvedba nije bila uspješna. Ako implikaturu negiramo govoreći „Neki ljudi su pljeskali, ali mislim da je izvedba bila u redu“ možemo reći da je implikatura poništena, no da je poricanje neuspješno, to jest, neuvjerljivo.

Ako teoriju o poricanju implicitnog sadržaja nadopunimo i razradimo uzimajući u obzir teorijsko razlikovanje između poništavanja, poricanja i opcionalnosti dobivamo uvjerljivu teoriju o snazi implikatura. Ako su implikature primarno značenje, to jest istaknuto značenje do kojega u određenom kontekstu dovodi automatsko zaključivanje tada ih se ne može poreći.

Spajanje ovih spoznaja s idejom da se razgovorne implikature mogu sagledati kao zaključci implicitnih argumenata dovodi nas do teorije prema kojoj je neuspješno poricanje implikatura zapravo logička kontradikcija. Naime, ako na razgovorne implikature gledamo kao na argumente koje slušatelj rekonstruira na temelju inputa koji mu pruža govornik, tada dodavanje kontradiktorne premise možemo gledati kao na logičku pogrešku koja dovodi do nekonzistentnog skupa vjerovanja. Sagledajmo primjere.

Ana dolazi po Branka kako bi skupa otišli na večeru, no on još nije spreman za izlazak.

Ana: Koliko ti još vremena treba?

Branko: Popij nešto.

Razgovorna implikatura je ta da Branku treba još neko vrijeme da se spremi te da Ana ima dovoljno vremena da popije piće prije polaska. Branko može implikaturu poništiti dodajući „ali spreman sam za čas“. Ipak, iako je takvo poništavanje moguće, poricanje nije takvo jer ono stvara nekonzistentan skup vjerovanja, naime, iskaz „Popij nešto“ otvara prostora implikaturi „treba mi još vremena da se spremim“, a poništavanje dodaje sadržaj „ali spreman sam za čas“. Spoj implicirane poruke i eksplicitnog poništavanja stvara nekonzistentan skup vjerovanja, a pri rekonstrukciji argumenta nekonzistentan skup premisa: „Treba mi više vremena da se spremim + (ali) spreman sam za čas“. Stoga, možemo reći da je poricanje neuvjerljivo iako je poništavanje moguće. Evo još dva primjera. Ana, Branko i Ida dio su projektnoga tima koji mora održati važan sastanak.

Ana: Gdje je Ida? Hoće li doći na sastanak?

Branko: Automobil joj se pokvario.

Implikatura Brankovog iskaza je ta da Ida neće moći doći na sastanak jer joj se automobil pokvario. Ipak, implikaturu možemo poništiti dodatkom „ali trebala bi stići“. Ovdje ponovo imamo nekonzistentan skup: „Ida neće doći na sastanak + Ida bi trebala stići na sastanak“. I zadnji, već poznati, primjer. Ivan, prema dogovoru, dolazi po Anu kako bi išli u kino.

Ivan: Jesi li spremna za kino?

Ana: Umorna sam.

Razgovorna implikatura je ta da je Anin umor razlog da ne ide u kino, to jest, preumorna je za odlazak u kino. Implikaturu može poništiti dodatkom „ali ipak želim u kino“. $\mathrm{Na}$ taj način dobivamo nekonzistentni skup: „Ne želim u kino + (ali ipak) želim u kino“. 
Ipak, kao što je već rečeno, poricanje implikature nikada nije binarno pitanje, već stvar gradacije. Ovisno o kontekstu, neka će poricanja biti uvjerljivija od drugih. Želim predložiti da je poricanje manje uvjerljivo što je manje konzistentan skup premisa i vjerovanja koji na temelju njega nastaje. Uvjerljivost premisa trebat će vrednovati od slučaja do slučaja. Razgovorne implikature, posebice partikularizirane razgovorne implikature na koje sam se usredotočila u ovome radu, veoma su kontekstualne, o tome, između ostalog, svjedoči njihova opcionalnost. Što više situacijskih varijabli poznajemo to ćemo bolje moći odrediti je li poricanje uspješno ili tvori nekonzistentan skup premisa. Predstavljanje implikatura, kao i njihovog poricanja, u obliku argumenta pomaže da jasnije sagledamo elemente koji ih sačinjavaju i odnose među njima - vodi li premisa do zaključka? Koji su elementi još potrebni da bi to bio slučaj? Kako se u takav argument uklapa opovrgavanje?

Pitanja vezana uz govornikovu odgovornost za izrečeno prelijevaju se iz pragmatike u epistemologiju i etiku te se na taj način nameću pitanja poput onog može li se pomoću pragmatičkih sredstava poput implikature svjedočiti ili lagati. Tradicionalni odgovor na ova pitanja negativan je. Fricker (2006) tako izraz „svjedočanstvo“ ograničava na doslovne i izravne izjave te izrijekom govori kako „gdje ono što se prenosi nije eksplicitno tvrđeno dolazi do smanjivanja odgovornosti za istinitost onog što govornik prenosi“ (2006: 247, endnota br. 8). U moralnoj teoriji uvriježena definicija laži isključuje sredstva poput implikatura, što je vidljivo iz tradicionalnih definicija poput ovih: „[l]až je izjava osobe koja ne vjeruje u njezin sadržaj i čija je namjera da netko povjeruje u nju“ (Isenberg 1973: 248) ili „[lagati je] tvrditi izjavu za koju se vjeruje da je neistinita, s namjerom da ju netko prihvati kao istinitu“" (Primoratz 1984: 54).

Nadam se kako ideje predstavljene u ovome radu, poput one da su implikature zaključci cjelovitog argumenta, a ne samo inferencije pri kojima koraci koji su doveli do zaključka nisu poznati, mogu doprinijeti pozitivnom odgovoru na pitanja možemo li svjedočiti i lagati implikaturama. Kada razgovorne implikature počnemo shvaćati kao primarno komunikacijsko značenje iskaza, a ne kao sekundarno nad kojim doslovni i izravni semantički sadržaj uvijek ima prednost možemo im pridati važnost koju zaslužuju te na taj način postaviti određene uvjete za njihovo poricanje. Davanjem prednosti mogućnosti da se razgovorne implikature (argumentacijski) izračunaju daje opravdanje slušateljima koji na temelju njih stvaraju vjerovanja te od govornika koji sadržaj implikature želi poreći traži da takvo poricanje ne bude samo izjednačeno s mogućnošću opovrgavanja, već da bude koherentno i uvjerljivo. Vjerujem kako se na taj način komunikacijska odgovornost ispravno prebacuje sa slušatelja na govornika.

\section{Zaključak}

Grice je razgovorne implikature odredio kao jezičnu pojavu koju je s jedne strane moguće racionalno rekonstruirati, a s druge kontekstualno ili verbalno poništiti. U radu sam 
krenula od ideje kako su, kada ih pomnije promotrimo, te dvije značajke razgovornih implikatura međusobno nekompatibilne. Mogućnost implikatura da se argumentacijski rekonstruiraju daje čvrst temelj vjerovanjima koja kompetentni jezični korisnik stvara na temelju govornikovog iskaza.

Rekonstrukciju implikatura vezala sam potom uz argumentaciju i racionalnost te sam ih prikazala kao razložne argumente. Razgovorne implikature možemo odrediti kao argumente u kojima govornik pruža razloge za konkluziju te od sugovornika ne očekuje odgovor, što ih razlikuje od klasične argumentacije pri kojoj dvije suprotstavljene strane brane vlastitu poziciju. Od klasičnih argumenata razlikuje ih i činjenica da je u njima eksplicitno izražena samo jedna premisa, a zaključak zajednički grade govornik i slušatelj u danoj razgovornoj situaciji. Rekonstrukcija implikatura, koja slušatelju pruža opravdanje za vjerovanje stvoreno na temelju neizrečenog sadržaja, odvija se post facto, dok se interpretacija odvija na temelju situacijski zadanog značenja, to jest značenja koje je u određenoj komunikacijskoj situaciji prominentno i do kojega slušatelj dolazi automatski.

$\mathrm{S}$ druge strane, ustaljeno je mišljenje da se razgovorne implikature u bilo kojem trenutku mogu poništiti. Ipak, valja odvojiti poništavanje sadržaja implikature od govornikovog poricanja činjenice da je njegov iskaz rezultat određene komunikacijske namjere. Za razliku od poništavanja implikature, poricanje može biti više ili manje uspješno. Predložila sam ideju prema kojoj je poricanje neuspješno, to jest neuvjerljivo, ako dovodi do nekonzistentnog skupa vjerovanja. Ako prihvatimo argumentacijski pogled na implikature takav nekonzistentan skup premisa (s logičke strane) i vjerovanja (s epistemičke strane) možemo smatrati indikatorom pogreške u zaključivanju. Shvaćanje poništavanja implikature kao (moguće) kontradikcije oslobađa slušatelja odgovornosti za vjerovanje nastalo na temelju neizrečenog sadržaja, što ima spoznajne i moralne posljedice vezane uz teorije o svjedočanstvu i laganju?

\section{Korištena literatura}

Åkerman, Jonas. 2014. „Infelicitous cancellation: The explicit cancellability test for conversational implicature revisited“. Australasian Journal of Philosophy http://dx.doi.org/10.1080/00048402. 2014.988738

Bach, Kent. 1994. „Conversational impliciture“. Mind and Language 9: 124-162

Blome-Tillmann, M. 2008. „Conversational implicature and the cancellability test“. Analysis 68. 156-160

Camp, Elisabeth. 2018. „Insinuation, Common Ground and the Conversational Record“. New Work on Speech Acts, ur. Daniel Fogal, Daniel W. Harris i Matt Moss, Oxford University Press $40-66$

7 Ovaj rad je financiralo Sveučilište u Rijeci projektom uniri-human-18-13. 
Carston, Robyn. 2002. Thoughts and Utterances: The Pragmatics of Explicit Communication. WileyBlackwell

Dahlman, Roberta Colonna. 2013. „Conversational Implicatures Are Still Cancellable“. Acta Analytica 28 (3):321-327

Fricker, Elisabeth. 2006. „Testimony and Epistemic Autonomy“. The Epistemology of Testimony. Jennifer Lackey i Ernest Sosa (ur.), 225-250, Clarendon Press

Gilbert, Michael A. 1991. „The Enthymeme Buster: A Heuristic Procedure for Position Exploration in Dialogic Dispute“. Informal Logic. Vol 13, No 3

Grice, Herbert Paul. 1987. „Logika i razgovor“, Kontekst i značenje, Nenad Miščević i Matjaž Potrč (ur.), Izdavački centar Rijeka, 55-67

Grice, Paul, H. 1995. „Logic and Conversation“, Studies in the Way of Words, Harvard University Press, Cambridge, Massachusetts; London, England, 22-40

Haugh, Michael. 2008. „The place of intention in the interactional achievement of implicature“. Mey J. L. and Kecskés I. (eds.) Intention, Common Ground and the Egocentric Speaker-Hearer. De Gruyter

Hitchcock, David. 2017. On Reasoning and Argument: Essays in Informal Logic and on Critical Thinking. Springer.

Horn, Laurence R. 1984. „Toward a new taxonomy for pragmatic inference: Q-based and R-based implicature“. Deborah Schiffrin, ur., Meaning, Form, and Use in Context: Linguistic Applications 11-42. Washington: Georgetown University Press.

Horn, Laurence R. 1989. A Natural History of Negation. University of Chicago Press.

Isenberg, Arnold. 1973. „Deontology and the Ethics of Lying“. Aesthetics and Theory of Criticism: Selected Essays of Arnold Isenberg, Chicago: University of Chicago Press, 1973. 245-264.

Jaszczolt, Kasia. M. 2016. Meaning in Linguistic Interaction: Semantics, Metasemantics, Philosophy of Language, Oxford University Press

Jaszczolt, Kasia. M. 2005. Default Semantics: Foundations of a Compositional Theory of Acts of Communication. Oxford: Oxford University Press

Jaszczolt, Kasia. M. 2010. „Default Semantics“. B. Heine and H. Narrog (ur.) The Oxford Handbook of Linguistic Analysis. Oxford: Oxford University Press. 215-246

Lee, James. J., i Pinker, Steven. 2010. „Rationales for indirect speech: The theory of the strategic speaker“. Psychological Review, 117 (3), 785-807

Macagno, Fabrizio and Walton, Douglas 2013. „Implicatures as Forms of Argument“ A. Capone et al. (ur.) Perspectives on Pragmatics and Philosophy. Berlin/New York: Springer, 203-224

Mazzarella, Diana; Reinecke, Robert; Noveck, Ira i Mercier, Hugo. 2018. „Saying, presupposing and implicating: how pragmatics modulates commitment“, Journal of Pragmatics 133, 15-27

Mercier, Hugo \& Sperber, Dan. 2017. The Enigma of Reason. Harvard University Press

Moldovan, Andrei. 2012. „Arguments, Implicatures and Argumentative Implicatures“. H. Jales Ribeiro (ur.), Inside Arguments: Logic And The Study of Argumentation. Cambridge, UK: Cambridge Scholars Publishers

Primoratz, Igor. 1984. „Lying and the "Methods of Ethics," International Studies in Philosophy, 16: 35-57.

Sbisà, Marina. 2001. “Intentions from the other side.” In G. Cosenza (ed.). Paul Grice's Heritage. Brepols: Turnhout.

Sperber, Dan i Wilson, Deirdre. 1986. Relevance: Communication and Cognition, Harvard University Press. 
Weiner, Matthew. 2006. „Are All Implicatures Cancellable?“, Analysis 66 (290): 127-130.

Wilson, Deirdre i Sperber, Dan. 2005. „Relevance Theory“, The Handbook of Pragmatics, Laurence Horn i Gergory Ward (ur.), Wiley-Blackwell.

Wilson, Deirdre i Sperber, Dan. 2012. Meaning and Relevance, Cambridge University Press. 